\title{
RESPONSE OF Fuchsia hybrida CUTTINGS TO FLURPRIMIDOL AND NAPHTHALENEACETIC ACID APPLICATION
}

\author{
Katarzyna Wróblewska \\ Department of Horticulture, Wroclaw University of Environmental and Life Sciences \\ pl. Grunwaldzki 24 A, 50-363 Wrocław, Poland \\ e-mail: katarzyna.wroblewska@up.wroc.pl
}

Received: 23.08.2012

\begin{abstract}
Auxins are the only compounds used in commercial plant propagation to stimulate rooting, although efforts have been made to find other efficient compounds. Another group of rooting promoters could be plant growth retardants (PGRs) which act as inhibitors of gibberellin synthesis. The aim of the experiment was to determine the effect of flurprimidol and naphthalene-1-acetic acid (NAA) applied by quick-dip method on rooting and development of Fuchsia hybrida 'Swingtime' cuttings and their subsequent growth. Anatomical analysis of the rooting process was also done. Flurprimidol and NAA did not influence the percentage of rooted fuchsia cuttings but increased the number of adventitious roots. Both compounds were involved in earlier formation of root primordia. Flurprimidol and NAA, used simultaneously or separately, increased the number and length of axillary shoots of fuchsia cuttings. The effect of flurprimidol on the number of roots and shoots was stronger than that of NAA, but diminished after transplanting the rooted cuttings. The influence of flurprimidol on axillary shoot length was weaker as its concentration increased.
\end{abstract}

Key words: growth retardants, auxins, adventitious roots, anatomical changes, axillary shoots

\section{INTRODUCTION}

The economical success of ornamental horticulture depends on production of plants of the highest quality in the shortest time of production. Growth regulators are commonly used to accelerate propagation and create required plant shape. Until now, auxins have been the main promoters of rooting of cuttings ( $\mathrm{H}$ a r tmann et al. 2002), although there have been made efforts to find other efficient compounds. Another group of compounds stimulating rooting are plant growth retardants (PGRs) (Davis and $\mathrm{Sankhla,}$ 1988), but they are not commercially used for this pur- pose. They act as inhibitors of gibberellin synthesis, thus suppress elongation of shoot internodes. In floriculture, retardants that compromise a nitrogen-containing heterocycle are the most commonly used, such as pyrimidines: ancymidol and flurprimidol, or some triazole-compounds such as paclobutrazol and uniconazole-P (R a d e $\mathrm{m}$ a c h e r, 2000). PGRs deactivate monooxygenases catalyzing oxidation of numerous metabolic pathways. Hence, apart from blocking gibberellin synthesis, PGRs influence the synthesis of sterols and abscisic acid (J a n kiew ic z, 1997). At the histological level of plant development, the effect of PGRs results from their impact on subapical shoot meristems which are responsible for internode elongation. According to G r o s s m a n n (1990), their lower concentrations inhibit cell elongation in this area, whereas the higher ones also suppress cell divisions. Apart from PGR concentration, their effectiveness depends on a number of factors, including the method of application, their persistence and plant response.

PGRs can be applied in many ways. In commercial cultivation, the most popular form of application is foliar spray or substrate drench ( $\mathrm{Schuch}, 1994)$. Foliar application usually requires higher doses and thus is related to a larger volume of spray solution, which is not of a neutral effect on the environment. Soil drench may have an excessive impact on plants, resulting in too strong height suppression and delayed development because of PGR survival in the substrate ( $\mathrm{H} \mathrm{w}$ a n g et al. 2008). Because of the need to reduce the influence of retardant effect on the environment, efforts have been made to find an alternative method of application that would allow to control the amount of the compound applied. Research on PGR-affected rooting conducted so far has involved soaking or dipping unrooted cuttings as well as a dipping root 
system of young plants ( $\mathrm{S} \mathrm{chuch}, 1994 ; \mathrm{Gent}$, 2004; $\mathrm{H}$ w a $\mathrm{ng}$ et al. 2008). These treatments provide a thorough coverage of submerged plant parts. Other methods included the following: encapsulated controlled-release systems (W i e s m a n et al. 2002), granular formulation (B un e l and C o c k re h a m, 2005; Grey et al. 2009) as well as recycled subirrigation supply (Milli on et al. 2002). Positive results were also obtained after mother plant treatment (W i e s m a n and Lavee, 1994).

Apart from determining plant shape, PGRs exhibit numerous side effects involved in plant quality, such as enhanced branching, accelerated flowering, increased chlorophyll content in leaves, and delayed aging ( $\mathrm{H} \mathrm{a} \mathrm{mid}$ and $\mathrm{W}$ i $11 \mathrm{iam} \mathrm{s}, 1997$; A b d u $11 \mathrm{ah}$ et al. 1998; K o z ak and Grodek, 2005; Y a d a v et al. 2005; Hwang et al. 2008; $\mathrm{Nizam}$ and $\mathrm{Te}-\mathrm{ch}$ ato, 2009). Moreover, they cause an increase in the amount of mechanical tissues, which makes plants less susceptible to lodging. Some physiological responses to PGRs, such as increased tolerance to stress factors (e.g. drought, frost and some fungus infections), reduced transpiration and water absorption enhance the survival of plants after transplanting (P r e $\mathrm{m} \mathrm{a} \mathrm{c} \mathrm{h} \mathrm{a} \mathrm{n} \mathrm{-}$ $\mathrm{d} r \mathrm{r}$ et al. 1997; K o z a k, 2006). Improved establishment after PGR treatment may also result from increased rhizogenesis (Abdi and Ascari-Raburi, 2009; Ni z a m and T e-ch at o, 2009).

Flurprimidol, investigated in the research, is widely used to control shoot elongation in cultivation of ornamental plants, such as Tibouchina and Melastoma of the order Myrtales, the same that fuchsia belongs to (Abdullah et al. 1998; Kozak and Grodek, 2005). It proved to be efficient in promoting adventitious root formation (B urkhart and Meyer, 1991). Flurprimidol is more effective through stem application than by root uptake. The poorest effectiveness of flurprimidol was shown in the case of foliar application (B un nell and Cockreha m, 2005).

The aim of the research was to determine the effect of flurprimidol and its cooperation with naphthalene-1-acetic acid (NAA) on rooting and development of Fuchsia hybrida 'Swingtime' cuttings as well as on subsequent growth of rooted cuttings. Anatomical analysis of changes taking place in cuttings was also undertaken. From the practical point of view, the study was undertaken in order to receive moderately compact and well branched plants in the shortest time of production.

\section{MATERIALS AND METHODS}

The experiment on propagation of Fuchsia hybrida 'Swingtime' by cuttings was carried out in the greenhouse of the Department of Horticulture, Wroclaw University of Environmental and Life Sciences, Poland, in March 2009 and 2010. Apical stem cuttings,
$4 \mathrm{~cm}$ in length, were treated with flurprimidol (contained in the commercial preparation Topflor $015 \mathrm{SL}$ ), naphtalene-1-acetic acid or flurprimidol with naphthalene-1-acetic acid in the following combinations (in $\mathrm{g}$ $\times \mathrm{dm}^{-3}$ ): flurprimidol: 0 (control cuttings); $0.075 ; 0.15$ and 0.3 ; NAA: $0.5 ; 1.0$ and 2.0; flurprimidol + NAA: $0.075+1.0 ; 0.15+0.5$.

Both compounds were applied by the quick-dip method: the basal ends of cuttings were dipped in the solutions for 5 second before placing in a rooting medium. The medium consisted of white peat, pine bark and perlite $3: 1: 1 ; \mathrm{V}: \mathrm{V}: \mathrm{V}, \mathrm{pH}$ 6.4. It was heated to a temperature of $21^{\circ} \mathrm{C}$. Low plastic tunnels were installed over the cuttings. The experiment was established in one factorial design with 6 replications, with 10 cuttings per each replication. The measurements, including percentage of rooted cuttings, number of roots, height of cuttings, as well as number and length of axillary shoots, were taken after 4 weeks of rooting. They were done in 3 replications for every cutting. Then, intact cuttings, not exposed to measurement, were planted into pots in peat substrate of $\mathrm{pH} 6.47$ containing (in $\mathrm{mg} \times \mathrm{dm}^{-3}$ ): $\mathrm{N}^{-N_{3}-145, \mathrm{P}} 119, \mathrm{~K} 263$, $\mathrm{Mg} 90, \mathrm{Ca} 1120$, and placed in a non-heated glasshouse. The experiment was established in 4 replications, with 5 plants per each replication. After 4 weeks of cultivation, the height of plants as well as the number and length of axillary shoots were measured.

The data of the study were subjected to analysis of variance, and the least significant differences between means were calculated by Tukey's test at $p=0.05$. The data concerning the percentage of rooted cuttings were first transformed according to Bliss function.

Anatomical analysis. For anatomical studies, additional cuttings of Fuchsia hybrida 'Swingtime' were prepared. They were treated with the following formulations (in $\mathrm{g} \mathrm{dm}^{-3}$ ) applied by quick-dip method: flurprimidol: 0.075 ; 0.15 ; NAA 1.0 . The last treatment was the control containing untreated cuttings. All cuttings were rooted in the conditions described above. During the first week after placing cuttings in the medium, cutting samples were collected for analysis every 24 hours, whereas subsequent collections took place every 2 days. Transactional sections were made from the basal part of cuttings, $0.5-1 \mathrm{~cm}$ long. Stem segments were embedded in paraffin, cut into $10 \mu \mathrm{m}$ sections using a microtome with disposable blades (Boeckeler MR2), stained with acid fuchsin and fast green and covered with Canadian balm. Microscopic analyses were performed under an optical microscope and photographed.

\section{RESULTS}

Regardless of the year of the experiment, no effect of flurprimidol and naphthaleneacetic acid on 
percentage of rooted cuttings, applied separately or together, was found. The only inhibitory effect could be observed after the application of NAA at the highest concentration during the second year of experiment. Both growth regulators did increase the number of adventitious roots in both years of research, but the influence of flurprimidol was stronger (Table 1). Regardless of the year of the experiment, flurprimidol at its highest concentration of $0.3 \mathrm{~g} \mathrm{dm}^{-3}$ increased the root number by $250 \%$ as compared to control cuttings. There was no significant difference between the effect of flurprimidol and flurprimidol combined with NAA.

The anatomical analysis indicated that the process of root formation in cutting shoots treated with flurprimidol occurred faster when it was administrated at the higher concentration and flurprimidol-induced rhizogenesis was only slightly delayed in comparison to NAA-determined changes. In shoots treated with flurprimidol at $0.075 \mathrm{~g} \mathrm{dm}^{-3}$, the first primordia emerged after 6 days of rooting (Fig. 1), and after 5 days as a result of flurprimidol application at $0.15 \mathrm{~g} \mathrm{dm}^{-3}$ (Fig. 2), whereas the same stage of primordium formation in NAA-treated cuttings was observed after 4 days (Fig. 3). Apparently, formed root meristems could be visible after 9, 7 and 5 days, respectively. The same stage of root primordia development in control cuttings was observed after 11 days of rooting. Root outgrowth through cutting cortex and getting outside took place after 11 days (Fig. 4), regardless of flurprimidol concentration, compared to 15 days for control cuttings (Fig. 5). Flurprimidol also increased the number of primordia in cuttings' shoots. In shoots treated with flurprimidol, 5 primordia appeared (Fig. 6), the same number as in shoots treated with auxin, while only up to 3 primordia were observed in control cuttings.

No effect of flurprimidol in lower concentrations on the height of fuchsia cuttings was observed. Only application of flurprimidol at a concentration of $0.3 \mathrm{~g} \times \mathrm{dm}^{-3}$ inhibited the growth of the main shoot, while a synergistic influence of flurpirimidol in both combinations introduced with NAA on suppression of cutting growth was recorded (Table 2). Our experiment showed the influence of both compounds on axillary shoot outgrowth. Flurprimidol and NAA, used separately, increased the number and length of axillary shoots, but the effect of retardant, applied alone or together with auxin, proved to be more advantageous (Table 2). This beneficial effect diminished after transplanting the rooted cuttings. The only treatment stimulating branching of fuchsia plants was flurprimidol at a concentration of $0.075 \mathrm{~g} \times \mathrm{dm}^{-3}$. The same treatment had the strongest effect on lateral shoot elongation. In fact, the positive influence of flurprimidol on the sum of axillary shoot length was weaker as its concentration increased (Table 3). The other treatment stimulating shoot growth was flurprimidol at a concentration of $0.075 \mathrm{~g} \times \mathrm{dm}^{-3}$ combined with NAA $1.0 \mathrm{~g} \times \mathrm{dm}^{-3}$. Irrespective of the year of the experiment, flurprimidol decreased the height of plants as compared to both control plants and the ones treated with NAA. Such effect resulted mainly from its influence in the second year of research.

Table 1

The influence of flurprimidol and NAA on rooting of cuttings of Fuchsia hybrida 'Swingtime'

\begin{tabular}{|c|c|c|c|c|c|c|c|}
\hline \multirow{3}{*}{ Treatment } & \multirow{3}{*}{$\begin{array}{l}\text { Concentration } \\
\left(\mathrm{g} \times \mathrm{dm}^{-3}\right)\end{array}$} & \multicolumn{6}{|c|}{ Feature } \\
\hline & & \multicolumn{3}{|c|}{ Rooting $^{*}(\%)$} & \multicolumn{3}{|c|}{ Number of roots $\left(\right.$ no. $\times$ cutting $^{-1}$ ) } \\
\hline & & 2009 & 2010 & Mean & 2009 & 2010 & Mean \\
\hline Control & --- & 81.4 & 77.7 & 79.6 & 4.9 & 5.5 & 5.2 \\
\hline \multirow{3}{*}{ Flurprimidol } & 0.075 & 76.9 & 77.7 & 77.3 & 11.7 & 9.7 & 10.7 \\
\hline & 0.15 & 90.0 & 68.9 & 79.5 & 11.2 & 9.9 & 10.6 \\
\hline & 0.3 & 83.9 & 66.6 & 75.3 & 12.5 & 13.7 & 13.1 \\
\hline \multirow{3}{*}{ NAA } & 0.5 & 90.0 & 75.0 & 82.5 & 11.0 & 7.3 & 9.2 \\
\hline & 1.0 & 90.0 & 71.6 & 80.8 & 7.1 & 6.7 & 7.0 \\
\hline & 2.0 & 90.0 & 61.2 & 75.6 & 10.9 & 7.8 & 9.4 \\
\hline \multirow{2}{*}{$\begin{array}{l}\text { Flurprimidol + } \\
\text { NAA }\end{array}$} & $0.075+1.0$ & 90.0 & 71.6 & 80.8 & 12.4 & 12.4 & 12.4 \\
\hline & $0.15+0.5$ & 83.9 & 63.9 & 73.9 & 10.6 & 9.2 & 9.9 \\
\hline \multirow{2}{*}{\multicolumn{2}{|c|}{$\begin{array}{l}\text { LSD for treatment } \\
\text { for treatment } x \text { year }\end{array}$}} & & 10.1 & & & 2.4 & \\
\hline & & & 14.3 & & & 3.4 & \\
\hline
\end{tabular}

* Data modified according to Bliss function 


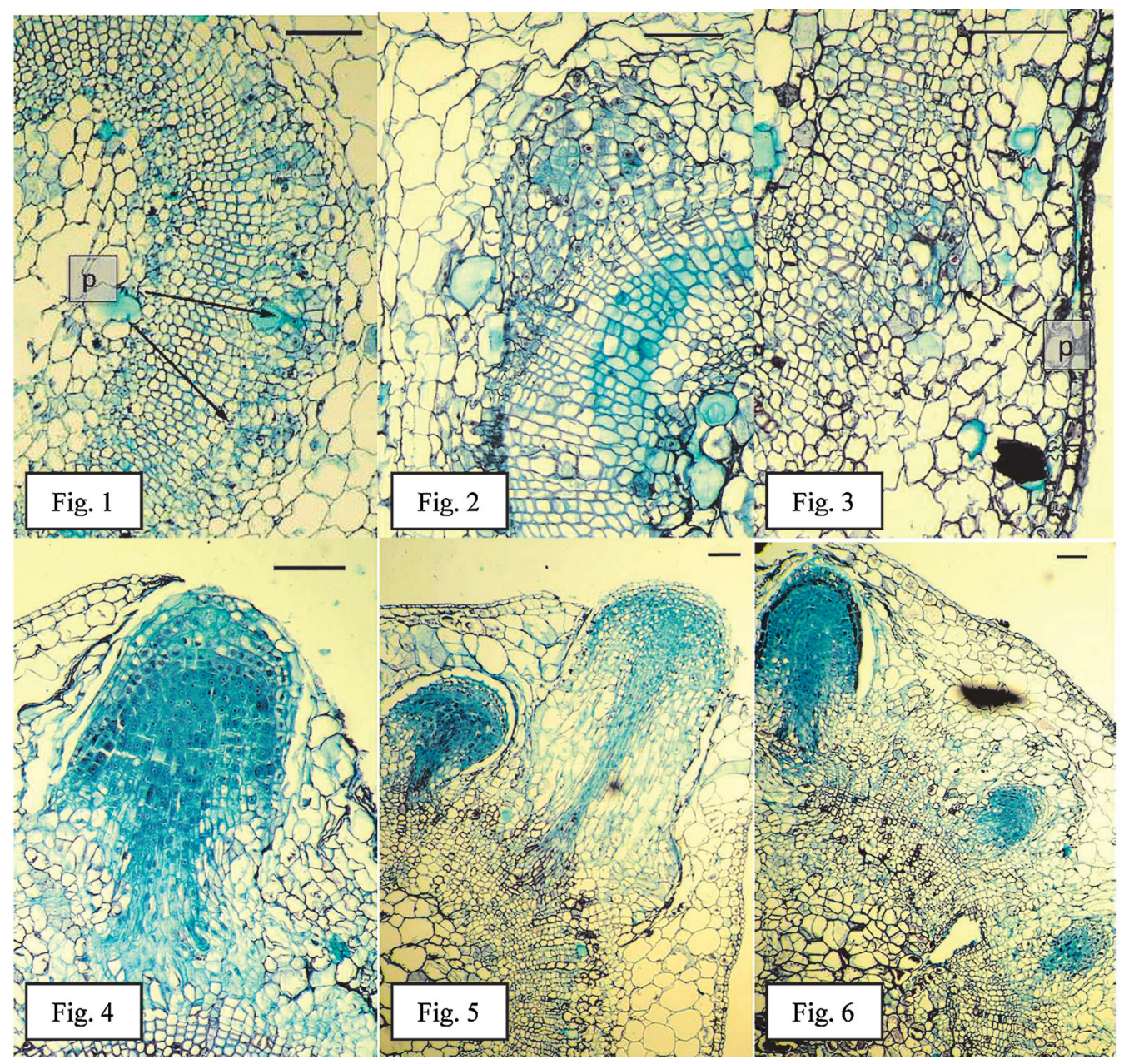

Figs 1-6. Transverse sections of the shoot of Fuchsia hybrida 'Swingtime' cuttings on the following days of rooting: 1. treated with flurprimidol at $0.075 \mathrm{~g} \mathrm{dm}^{-3}$, day 7 , showing adventitious root primordium (p) formation in the cambium and phloem region; 2. treated with flurprimidol at $0.15 \mathrm{~g} \times \mathrm{dm}^{-3}$, day 6 , showing the formation of an adventitious root primordium; 3. treated with NAA at $1.0 \mathrm{~g} \times \mathrm{dm}^{-3}$, day 5 , showing cell divisions in an adventitious root primordium (p); 4. treated with flurprimidol at $0.15 \mathrm{~g} \mathrm{dm}^{-3}$, day 12, showing an adventitious root developing through tissues of the shoot, 5. control, day 16 , showing an adventitious root developing through the tissues of the shoot; 6 . treated with flurprimidol at $0.075 \mathrm{~g} \times \mathrm{dm}^{-3}$, day 7 , showing three root primordia. Bars equal $100 \mu \mathrm{m}$.

\section{DISCUSSION}

One of hormonal responses to PGRs is a considerable lowering of the level of gibberellins, known for their strong inhibition of rooting. Hence, a decrease in gibberellin content, caused by PGRs, can result in the stimulation of rhizogenesis. The treatment of intact plants with PGR is expressed by an increased root/shoot ratio (Grossmann, 1990), whereas in unrooted cuttings the stimulatory effect on rhizogenesis can be expressed by an increased percentage of rooting as well as the increased number and length of adventitious roots (D arwati et al. 1993; Wi e s man and Lavee, 1994; Hwang et al. 2008; Kepenek and $\mathrm{K}$ aro $1 \mathrm{u}, 2011)$.

Apart from reducing the level of natural gibberellin acid, PGRs also affect the level of other plant hormones, including auxins and cytokinins, which determine shoot and root architecture. The effect of PGRs on the level of natural auxins is not of a clear-cut significance - they can either increase or decrease natural IAA concentration values in tissues $(\mathrm{P} \mathrm{a} \mathrm{n}$ and Gui, 1997; Shan an and Soliman, 2011). Nevertheless, numerous researches have proved that it is justified to apply PGRs combined with exogenous auxins. The simultaneous use of both these regulators has proved to be more effective than each of them alone on adventitious root formation in cuttings of many plant species, both herbaceous, like Phaseolus aureus L. (P a n and $\mathrm{Z}$ h a o 1994), and woody, such as Pinus caribaea var. hondurensis Morelet (He nrique et al. 2006) and Delonix regia (Boger.) Raf. (A b d i and Ascari-Raburi, 2009). The synergistic effect 
of growth retardants and exogenous indole-3-butyric acid (IBA) or NAA on rooting has also been observed in in vitro cultures $(\mathrm{B} \mathrm{urkhart}$ and $\mathrm{Meyer}$, 1991; Wi e s m an and Lavee, 1994; Niza m and $\mathrm{Te}-\mathrm{c}$ h a t o, 2009). The mechanism of this phenomenon has not been unequivocally explained so far. It is believed that the cooperation of these two groups of plant growth regulators can be connected with hormone concentration in particular stages of rhizogenesis. A high concentration of auxins is indispensable, as far as the first stage of rooting, i.e. induction of adventitious roots, is concerned. The reducing effect of gibberellins is revealed in the second stage of root development, in which intensive cell divisions take place. PGRs, as antigibberellins, are probably active in the same stage of rhizogenesis. The positive effects of sequential application of auxins and retardants (IBA followed by the retardant) confirm this hypothesis ( $\mathrm{Pan}$ and $\mathrm{Zh}$ a o, 1994). Another explanation of the synergistic effect of auxins and PGRs on rooting can be their stimulatory effect on peroxidase activity, which is responsible for auxin metabolism ( $\mathrm{Pan}$ and $\mathrm{Gui}$, 1997). This explanation may also be connected with subsequent developmental stages of adventitious root formation, as changes in peroxidase isoform pattern and activity are regarded as biochemical markers of rooting phases (S y ros et al. 2004). Anatomical analysis of Fuchsia cuttings corroborates PGR-induced stimulation of primordia formation but it does not allow concluding that there exists any relationship between PGRs and stages of adventitious root development.

Contrary to most of observations focused on PGR and auxin effect on rooting, none of the methods of treatment (PGR alone or with auxin) influenced the percentage of rooting of Fuchsia cuttings. Moreover, the cuttings showed a stronger positive response in terms of root number to flurprimidol or NAA comparable to their simultaneous application. Such effect may be associated with a strong PGR influence on cytokinin level in plants. This relation proves, at the same time, to be much more unequivocal than in the case of auxins, as PGR application usually increases the level of endogenous cytokinins in shoot tissues (J a n ki ew i c z, 1997; R a d e m a c h e r, 2000). It may also occur as a consequence of a decreased level of gibberellins, which act antagonistically on cytokinin activity in apical shoot meristems ( $\mathrm{S} \mathrm{h}$ an i et al. 2006). The strong promoting influence of flurprimidol on branching of Fuchsia cuttings may also suggest the increase in cytokinin level after PGR application. Cytokinins are responsible for releasing from apical dominance. Many papers have documented that PGR treatment stimulates growth of axillary shoots in some plant species, both in vivo and in vitro $(\mathrm{H}$ a $\mathrm{m}$ i d and Williams, 1997; Kozak and Grodek,
2005, A bdelgadir et al. 2009; Kepenek and $\mathrm{K}$ aro $1 \mathrm{u}, 2011$ ). The poorer effect of flurprimidol on axillary shoot development after transplanting rooted cuttings may be a consequence of single application of this retardant. To obtain plants with abundant tillering, it may be necessary to repeat the application after transplanting (M illi o n et al. 2002).

\section{CONCLUSIONS}

1. Regardless of the year of the experiment, flurprimidol and NAA did not influence the percentage of rooting of Fuchsia hybrida 'Swingtime' cuttings, but increased the number of adventitious roots, flurprimidol being more efficient than NAA. Both compounds were involved in the earlier formation of adventitious root primordia.

2. Flurprimidol and NAA, used simultaneously or separately, increased the number and length of axillary shoots in fuchsia cuttings, but the effect of growth retardant was stronger. The only treatment stimulating branching of fuchsia plants was flurprimidol at a concentration of $0.075 \mathrm{~g} \mathrm{dm}^{-3}$. The positive influence of flurprimidol on the sum of axillary shoot length was weaker as its concentration increased.

\section{Acknowledgements}

Research supported by the Ministry of Science and Higher Education of Poland as the part of statutory activities of Department of Horticulture, Wroclaw University of Environmental and Life Sciences.

\section{REFERENCES}

Abdelgadir H.A., Johnson S.D., Van Staden J. 2009. Promoting branching of a potential biofuel Jatropha curcas $\mathrm{L}$. by foliar application of plant growth regulators. J. Plant Growth Regul. 58: 287-295. http:// dx.doi.org/10.1007/s10725-009-9377-9

Abdi G., Ascari-Raburi N. 2009. Enhancement of IBA, urea-phosphate, paclobutrazol and their combinations on rooting of royal poinciana (Delonix regia) stem cuttings. Am-Eurasian J. Sustain Agric. 6 (2): 132-136.

Abdullah T., Malek A.A., Ahmad S.H. 1998. Chemical manipulation of growth and flowering in potted Melastoma decemfidum and Tibouchina semidecandra. Acta Hort. 454: 297-301.

Bunnell B.T., Cockreham S.D. 2005. New innovations with flurprimidol use on turfgrass, containerized ornamentals, and landscape ornamentals. Proc. 32th Ann. Meeting of Plant Growth Regulation Society of America: 101 (abstract).

Burkhart L.F., Meyer M.M. 1991. The gibberellin synthesis inhibitors, ancymidol and flurprimidol, promote in 
vitro rooting of white pine microshoots. Plant Cell Rep. 10: 475-476. http://dx.doi.org/10.1007/BF00233818

Darwati I., Rosita SMD, Hasanah M., Oniki M. 1993. The effect of plant growth regulator on the root growth of clove marcotting. J. Spice and Medicinal Crops, 11 (1): 31-35.

Davis T.D., Sankhla N. 1988. Effect of shoot growth retardants and inhibitors on adventitious rooting. In: Davies T.D., Haissig B.E., Sankhla N. (eds.) Adventitious Root Formation in Cuttings. Dioscorides Press, Portland, Oregon: 174-184.

Gent M.P.N. 2004. Efficacy and persistence of paclobutrazol applied to rooted cuttings of Rhododendron before transplant. HortSci. 39(1):105-109.

Grey T.L., Czarnota M., Potter T., Bunnel B.T. 2009. Timed release of flurprimidol from a granular formulation in mulches and sand. HortSci. 44 (2): $512-515$.

Grossmann K. 1990. Plant growth retardants as tools in physiological research. Physiol. Plant 78: 640-648. http://dx.doi.org/10.1034/j.1399-3054.1990.780422.x

Hamid M.M., Williams R.R. 1997. Effect of different types and concentrations of plant growth retardants on Sturt's desert pea (Swainsona formosa). Sci. Hortic. 71: 79-85. http://dx.doi.org/10.1016/S0304-4238(97) 00107-6

Hartmann H.T., Kester D.E., Davies F.T., Geneve R.L. 2002. Principles of propagation by cuttings. In: Plant propagation, principles and practices. Prentice Hall, Upper Saddle River, New Jersey: 278-291.

Henrique A., Campinhos E.N., Ono E.O., Zambello de Pinho S. 2006. Effect of plant growth regulators in the rooting of Pinus cuttings. Braz. Archives Biol. Technol. 49(2): 189-196. http://dx.doi. org/10.1590/S1516-89132006000300002

Hwang S.J., Lee M.Y., Sivanesan I., Jeong B.R. 2008. Growth control of kalanchoe cultivars Rako and Gold Strike by application of paclobutrazol and uniconazole as soaking treatment of cuttings. Afr. J. Biotechnol 7 (22): 4212-4218.

Jankiewicz L.S. 1997. Retardanty i niektóre inne syntetyczne inhibitory wzrostu oraz wybrane substancje modyfikujące wzrost. [In:] L.S. Jankiewicz (ed.) Regulatory wzrostu i rozwoju roślin. Część 1. Właściwości i działanie. Wyd. Nauk. PWN, Warszawa: 108-123. (in Polish)

Kepenek K., Karo 1u Z. 2011. The effects of paclobutrazol and daminozide on in vitro micropropagation of some apple (Malus domestica) cultivars and M9-rootstock. Afr. J. Biotechnol. 10 (24): 4851-4859.

Kozak D., Grodek J. 2005. The consequent effect of growth retardants on the growth and development of Tibouchina urvilleana Cogn. shoots in vitro. Acta Sci. Pol. Hortorum Cultus, 4 (2): 123-128.

Kozak D. 2006. The effect of growth retardants applied in vitro on the acclimatization and growth of Tibouchina urvilleana cogn. in vivo. Acta Sci. Pol., Hortorum Cultus, 5(1): 65-70.

Million J.B., Barrett J.E., Nell T.A., Clark D.G. 2002. One time vs. continuous application of paclobutrazol in subirrigation for the production of bedding plants. HortSci. 37(2):345-347.

Niza m K., Te-chat o S. 2009. Optimizing of root induction in oil palm plantlets for acclimatization by some potent plant growth regulators (PGRs). J. Agric. Technol. 5(2):371-383

Pan R., Gui H. 1997. Physiological basis of the synergistic effects of IBA and triadimefon on rooting of mung bean hypocotyls. Plant Growth Regul. 22: 7-11.

Pan R., Zha o Z. 1994. Synergistic effects of plant growth retardants and IBA on the formation of adventitious roots in hypocotyl cuttings of mung bean. Plant Growth Regul. 14: 15-19.

Premachandra G.S., Chaney W.R., Holt H.A. 1997. Gas exchange and water relations of Fraxinus americana affected by flurprimidol. Tree Physiol. 17: 97-103. http://dx.doi.org/10.1093/treephys/17.2.97

Rademacher W. 2000. Growth retardants: effects on gibberellin biosynthesis and other metabolic pathways. Annu. Rev. Plant Physiol. Plant Mol. Biol. 51: 501-31

Schuch U.K. 1994. Response of Chrysanthemum to uniconazole and daminozide applied as dip to cuttings or as foliar spary. J Plant Growth Regul. 13: 115-121. http://dx.doi.org/10.1007/BF00196374

Shanan N. T.A., Soliman A.Sh. 2011. Response of snapdragon plants to pinching and growth retardants treatments. Am.-Eurasian J. Sustain. Agric. (2): 150-157.

Shani E., Yanai O., Ori N. 2006. The role of hormones in shoot apical meristem function. Curr. Opin. Plant Biol. 9: 484-489. http://dx.doi.org/10.1016/j.pbi. 2006.07.008

Syros T., Yupsanis T., Zafiriadis H., Economou A., 2004. Activity and isoforms of peroxidases, lignin and anatomy, during adventitious rooting in cuttings of Ebenus cretica L. J. Plant Physiol. 161: 69-77. http://dx.doi.org/10.1078/0176-1617-00938

Wiesman Z., Lavee S. 1994. Vegetative growth retardation, improved rooting and viability of olive cuttings in response to application of growth retardants. Plant Growth Regul. 14: 83-90. http://dx.doi.org/10.1007/ BF00024145

Wiesman Z., Markus A., Wybraniec S., Schwartz L., Wolf D. 2002. Promotion of rooting and development of cuttings by plant growth factors formulated into a controlled-release system. Biol. Fertil Soils 36:330-334. http://dx.doi.org/10.1007/ s00374-002-0553-6

Yadav R.K., Rai N., Yadav D.S., Asati B.S. 2005. Use of paclobutrazol in horticultural crops - a review. Agric. Rev. 26 (2): 124 - 132. 


\section{Reakcja sadzonek \\ fuksji ogrodowej Fuchsia hybrida na fluropirimidol i kwas naftylo-1-octowy}

\section{Streszczenie}

Auksyny to jedyna grupa związków stosowanych $\mathrm{w}$ produkcji roślin $\mathrm{w}$ celu stymulowania ukorzeniania, chociaż podejmowane są wysiłki w celu znalezienia innych skutecznych preparatów. Inną grupą stymulatorów ukorzeniania mogą być retardanty wzrostu roślin, których działanie polega na hamowaniu syntezy giberelin. Celem doświadczenia była ocena wpływu fluropirimidolu i kwasu naftylooctowego podawanych metodą quick-dip na ukorzenianie i rozwój sadzonek fuksji ogrodowej 'Swingtime' oraz ich wzrost następczy. Przeprowadzono także analizę anatomiczną procesu ukorzeniania. Fluropirimidol i NAA nie wpłynęły na procent ukorzenienia sadzonek fuksji, zwiększyły natomiast liczbę korzeni przybyszowych na sadzonkach. Obydwa związki przyspieszały tworzenie zawiązków korzeni przybyszowych. Fluropirimidol i NAA, zastosowane razem lub osobno, zwiększały liczbę i długość pędów bocznych na sadzonkach. Wpływ fluropirimidolu na liczbę korzeni i pędów bocznych był silniejszy niż NAA, ale zanikał po przesadzeniu ukorzenionych sadzonek. Wpływ fluropirimidolu na długość pędów bocznych słabł wraz z jego wzrastającym stężeniem. 